\title{
Genetic testing and research in Lynch Syndrome - is it a choice or a responsibility?
}

\author{
Lorraine Cowley $^{1 *}$, Janice McLaughlin², Tracy Finch ${ }^{3}$, Emma Clavering $^{2}$, John Burn ${ }^{1}$ \\ From 14th Annual Meeting of the Collaborative Group of the Americas on Inherited Colorectal Cancer \\ Dallas, TX, USA. 12-13 October 2010
}

\section{Background}

This project explores experiences of an extended family; one of the first internationally to have the MLH 1 gene characterised [1], causing what has become known as Lynch Syndrome. The paper focuses on how participants frame notions of choice and responsibility in the context of genetic testing and research.

\section{Method}

A sample of 15 from 50 of the biomedical family who tested either positive or negative for MLH1 was invited to discuss family relationships. The methodology used multiple qualitative interviews and visual methods including photo elicitation, social mapping and engagement with the genetic family pedigree. Data was analysed from a narrative perspective [2].

\section{Results}

Choice in genetic testing and research does not appear to be the key value for participants in this study; instead they are influenced by a sense of responsibility [3]. Choice for them is an important right, one exercised by other family members who declined a test. Their narratives however, illustrate three moral imperatives that transform choice into responsibility; they are: responsibility to children, to self and to scientific progress (the greater good).

Participants who were parents discussed a paramount duty of care to children as the main motivating factor when accepting a test. Those whose parents had declined genetic testing experienced disappointment and referred to the right to choose as a means of ethically managing that.

\footnotetext{
* Correspondence: Lorraine.Cowley@ncl.ac.uk

${ }^{1}$ Institute of Human Genetics, Newcastle University, International Centre for Life, Central Parkway, Newcastle upon Tyne, NE1 3BZ, UK

Full list of author information is available at the end of the article
}

Genetic testing was also viewed in the context of a Health Belief model [4,5] framing those who declined testing as neglectful of a moral imperative to self care. Participants sometimes conflated choosing a genetic test with choosing life and used cautionary tales of those who declined testing and developed cancer to justify decisions and persuade others considering a test.

Within this moral framework an obligation to participate in genetic research is narrated from differing perspectives. A pioneering identity from being the first known family characterising the gene gave participants value and led to kin-like reciprocation invoking a desire to repay perceived medical investment in the "family". A strong belief was held that genetics is key to the advancement of medicine.

\section{Conclusion}

Genetic testing and participation in research is viewed as both a choice and a responsibility. The apparent conflict between rights to autonomy and moral imperatives of responsibility operate as caveats for preferencing or defending choice over responsibility or responsibility over choice. These insights contribute to important narratives about cultural engagement with the new genetics and have implications for practice.

\section{Acknowledgements \\ Research participants, Cancer Research UK, Bayer}

\section{Author details}

Institute of Human Genetics, Newcastle University, International Centre for Life, Central Parkway, Newcastle upon Tyne, NE1 3BZ, UK. ²PEALS (Policy, Ethics and Life Sciences Research Centre), Newcastle University Citywall, Citygate, St. James' Boulevard, Newcastle upon Tyne, NE1 4JH, UK. ${ }^{3}$ Institute of Health and Society, Newcastle University, Baddiley-Clark Building, Richardson Road, Newcastle upon Tyne, NE2 4AX, UK.

Published: 10 March 2011 


\section{References}

1. Kolodner R, Hall N, Lipford J, Kane M, Morrison P, Finan P, Burn J,

Chapman P, Earabino C, Merchant Eea: Structure of the human MLH1

locus and analysis of a large hereditary non polyposis colorectal

carcinoma kindred for mlh1 mutations. Cancer Research 1995, 55:242-248.

2. Riessman C: Analysis of personal narratives. In Handbook of interview research Gubrium J, Holstein JA 2002.

3. Polzer J: Choice as Responsibility. In Genetic Governance. Hoboken: Routledge;Bunton R, Petersen A 2005:74-85.

4. Becker MH, Don PH, Kasl SV, Kirscht JP, Maiman LA, Rosenstock IM: Selected Psychosocial Models and Correlates of Individual HealthRelated Behaviors. Medical Care 1977, 15:27-46.

5. Joseph G, Burke NJ, Tuason N, Barker JC, Pasick RJ: Perceived Susceptibility to Illness and Perceived Benefits of Preventive Care: An Exploration of Behavioral Theory Constructs in a Transcultural Context. Health Education \& Behavior 2009, 36:71S-90S.

doi:10.1186/1897-4287-9-S1-P6

Cite this article as: Cowley et al:: Genetic testing and research in Lynch Syndrome - is it a choice or a responsibility? Hereditary Cancer in Clinical Practice 2011 9(Suppl 1):P6.

\section{Submit your next manuscript to BioMed Central} and take full advantage of:

- Convenient online submission

- Thorough peer review

- No space constraints or color figure charges

- Immediate publication on acceptance

- Inclusion in PubMed, CAS, Scopus and Google Scholar

- Research which is freely available for redistribution

Submit your manuscript at www.biomedcentral.com/submit 